\title{
Decreasing in Acid Number of Patchouli Oil by Different Natural Adsorbent and Variation of Contact Time
}

\author{
Tri Esti Purbaningtias ${ }^{1}$, Bayu Wiyantoko ${ }^{1}$, Puji Kurniawati ${ }^{1}$, Mustika Kusuma Sari ${ }^{2}$ \\ ${ }^{1}$ Program Diploma III Analis Kimia, FMIPA, Universitas Islam Indonesia, Jogjakarta; \\ ${ }^{2}$ Mahasiswa Program Diploma III Analis Kimia, FMIPA, Universitas Islam Indonesia, \\ Jogjakarta
}

\begin{abstract}
One way for improving (of improving atau to improve) the quality of patchouli oil was to reduce the acid number. Acid number could be reduced with the use of natural adsorbents. The decreasing percentage acid number of patchouli oils using adsorbents zeolites, bentonite, rub ash, and activated carbon, respectively $4.71 \% ; 1.45 \% ; 7,84 \%$; and $4.64 \%$. The contact time could influence the decrease in acid number of patchouli oil. The longer the contact between adsorbent and oil could caused a decrease in acid number. Maximum contact time for rub ash was 15 hours with a maximum adsorption capacity of $14,34 \%$ for 0.1 gram adsorbent.
\end{abstract}

Keywords: Patchouli oil, acid number, natural adsorbent, contact time

\begin{abstract}
ABSTRAK
Salah satu paya peningkatan kualitas minyak nilam adalah dengan menurunkan bilangan asamnya. Bilangan asam dapat diturunkan dengan menggunakan adsorben alam. Prosentase penurunan bilangan asam minyak nilam menggunakan adsorben zeolit, bentonit, abu gosok, dan karbon aktif berturut-turut adalah 4,71\%; 1,45\%; 7,84\%; dan 4,64\%. Waktu kontak dapat mempengaruhi penurunan bilangan asam minyak nilam. Semakin lama waktu kontak antara adsorben dan minyak dapat menyebabkan semakin besarnya penurunan bilangan asam. Waktu kontak maksimum untuk abu gosok adalah 15 jam dengan kapasitas maksimum adsorpsi sebesar $14,34 \%$ per 0,1 gram adsorben.
\end{abstract}

Kata-kata kunci:minyak nilam, bilangan asam, adsorben alam, waktu kontak

\section{Pendahuluan}

Indonesia merupakan penghasil minyak atsiri yang cukup penting diperdagangan di dunia, terutama untuk minyak nilam. Sekitar $90 \%$ pemasok minyak nilam dunia berasal dari Indonesia. Pada tahun 2011, Indonesia mengekspor $66.742,46$ ton minyak atsiri dimana sekitar $50 \%$ dari jumlah tersebut adalah minyak nilam. Pada tahun 2011 ekspor minyak atsiri mencapai 438,16 juta US\$ (Kemendag, 2011). Hal ini dimungkinkan karena tanaman yang berpotensi sebagai penghasil minyak atsiri banyak ditemukan di Indonesia.
Salah satu tanaman penghasil minyak atsiri yang telah dikenal luas oleh masyarakat Indonesia adalah tanaman nilam (Pogostemon cablin ). Tanaman ini dapat tumbuh dengan mudah di berbagai wilayah di Indonesia, seperti di Pulau Sumatra, Jawa, maupun Sulawesi. Dari berbagai macam minyak atsiri yang ada di Indonesia, minyak nilam merupakan penghasil devisa negara yang terbanyak dan menjadi primadona dari perdagangan Internasional. Salah satu sifat minyak nilam yang khas adalah daya fiksasinya yang cukup tinggi. Hal ini merupakan keunggulan dari minyak nilam yang tidak 
memungkinkan untuk disubtitusi oleh minyak atsiri sintesis. Oleh sebab itu minyak nilam harus diekstrak dari nilam alami.

Menurut Sastrohamidjojo (2004), di pasar perdagangan internasional nilam dijual dalam bentuk minyak dan dikenal dengan nama " patchouli oil ". Dari berbagai macam minyak atsiri yang ada di Indonesia, minyak nilam merupakan penghasil devisa negara yang terbanyak dan menjadi primadona dari perdagangan Internasional. Salah satu sifat minyak nilam yang khas adalah daya fiksasinya yang cukup tinggi. Hal ini merupakan keunggulan dari minyak nilam yang tidak memungkinkan untuk disubtitusi oleh minyak sintesis. Oleh sebab itu minyak nilam harus diekstrak dari nilam alami.

$$
\text { Mutu minyak nilam yang }
$$
dihasilkan harus memenuhi standar mutu perdagangan antara lain dalam hal warna, berat jenis, indeks bias, dan putaran optik. Mutu minyak nilam dikatakan baik jika memenuhi syarat atau mendekati standar mutu perdagangan. Pada minyak nilam faktor yang menentukan mutu dari minyak tersebut baik atau tidak adalah seberapa besar kadar patchouli alkoholnya dan seberapa kecil bilangan asam minyak tersebut.

Penurunkan bilangan asam pada minyak nilam dapat dilakukan dengan metode adsorpsi. Proses adsorpsi dengan bentonit pada minyak nilam dapat mengubah warna minyak nilam dari coklat tua menjadi kuning muda dan menurunkan kandungan Fe (Sariadi, 2012). Penggunaan Na-EDTA sebagai senyawa pengkelat juga dapat meningkatkan kemurnian minyak nilam (Alam, 2007). Proses adsorpsi untuk meningkatkan kualitas minyak nilam cukup efektif dan mudah dalam mengaplikasikannya.

Proses adsorpsi untuk meningkatkan kualitas minyak nilam dengan menurunkan bilangan asamnya dengan menggunakan adsorben alam dapat meningkatkan nilai ekonomis minyak. Saat ini adsorben yang materialnya berasal dari alam cukup mudah ditemukan dan harganya cukup murah. Penggunaan adsorben secara umum bertujuan untuk penyerapan (mengadsorpsi) komponenkomponen bahan pengotor dalam minyak atau senyawa trigliserida (Foletto dkk.,2006).Beberapa penelitian yang mengkaji kesuksesan penggunaan adsorben alam pada berbagai adsorpsi antara lain Foletto dkk (2006) tentang penjernihan minyak biji kapas menggunakan bentonit teraktivasi asam, Topallar (1998) tentang penjernihan minyak dari biji bunga matahari menggunakan bentonit, dan Purwaningsih dkk (2000) tentang pemanfaatan karbon aktif cangkang kelapa sawit sebagai adsorben pada limbah cair kayu lapis. Penelitian ini memanfaatkan adsorben alam yang mudah ditemukan dan sudah dijual bebas, walaupun masih terbatas, yaitu bentonit, zeolit, karbon teraktivasi, dan abu gosok.

\section{Tujuan Penelitian}

Tujuan penelitian tentang penurunan bilangan asam minyak nilam dengan pemanfaatan adsorben alam adalah:

1. Mengetahui perbedaan jenis adsorben alam pada penurunan bilangan asam minyak nilam.

2. Mengetahui pengaruh waktu kontak adsorpsi terhadap penurunan bilangan asam minyak nilam.

\section{Metode Penelitian} Penentuan bilangan asam minyak nilam
tanpa adsorben (SNI-06-2388-2006)

Minyak nilam diambil sebanyak 4 gram $\pm 0,05$ gram dan dimasukan kedalam Erlenmeyer $250 \mathrm{~mL}$, kemudian dilarutkan dalam $5 \mathrm{~mL}$ etanol netral lalu dilakukan 
titrasi dengan larutan standar KOH $0,1 \mathrm{~N}$ dengan indikator phenolptalein sampai warna merah muda, dicatat volume larutan standar $\mathrm{KOH}$ 0,1 $\mathrm{N}$ yang dibutuhkan serta dihitung bilangan asam pada minyak nilam.

\section{Penetuan bilangan asam minyak nilam dengan beberapa adsorben}

Padatan adsorben (zeolit, bentonit, abu gosok, dan karbon aktif) ditimbang sebanyak 0,1 gram dimasukan kedalam tabung reaksi lalu ditambah $5 \mathrm{~mL}$ minyak nilam, didiamkan selama 6 jam, setelah itu dipisahkan minyak nilam dari adsorben dan ditimbang sebanyak 4 gram $\pm 0,05$ gram. Minyak tersebut dimasukkan ke dalam labu Erlenmeyer $250 \mathrm{~mL}$ dan dilarutkan dalam $5 \mathrm{~mL}$ etanol, netral serta ditambah 5 tetes indikator phenolptalein. Selanjutnya minyak dititrasi dengan larutan $\mathrm{KOH} \quad 0,1 \quad \mathrm{~N}$ yang telah distandarisasi sampai warna merah muda, dicatat volume $\mathrm{KOH}$ yang dibutuhkan serta dihitung bilangan asam minyak nilam.

\section{Variasi waktu kontak menggunakan adsorben yang terbaik}

Pengaruh waktu kontak adsorpsi terhadap penurunan bilangan asam minyak nilam dilakukan dengan menggunakan adsorben yang memiliki aktivitas paling. Padatan adsorben yang terbaik dalam penurunan bilangan asam minyak nilam (salah satu dari zeolit, bentonit, abu gosok, dan karbon aktif) ditimbang sebanyak 0,1 gram, dimasukan kedalam tabung reaksi lalu ditambah $5 \mathrm{~mL}$ minyak nilam, didiamkan selama 3,6,9,12,15, dan 21, setelah itu minyak nilam dipisahkan dari adsorben dan ditimbang sebanyak 4 gram $\pm 0,05$ gram, kemudian dimasukkan kedalam labu Erlenmeyer $250 \mathrm{~mL}$. Minyak tersebut dilarutkan dalam $5 \mathrm{~mL}$ etanol netral dan ditambah 5 tetes indikator phenolptalein, selanjutnya dititrasi dengan larutan $\mathrm{KOH} 0,1 \mathrm{~N}$ sampai warna merah muda, dicatat volume $\mathrm{KOH}$ yang dibutuhkan serta dihitung bilangan asam minyak nilam.

\section{Hasil dan Pembahasan}

\section{Pengaruh Jenis Adsorben}

Penelitian ini bertujuan untuk mengetahui pengaruh jenis adsorben dan waktu kontak terhadap penurunan bilangan asam minyak nilam dalam upaya peningkatan kualitasnya. Bilangan asam minyak nilam ditentukan dengan metode alkalimetri, metode ini termasuk ke dalam reaksi netralisasi yakni reaksi antara ion hidrogen yang berasal dari asam dengan ion hidroksida yang berasal dari basa untuk menghasilkan air yang bersifat netral. Alkalimetri sendiri adalah penetapan kadar senyawa - senyawa asam dengan menggunakan larutan baku basa.

Penambahan adsorben ke dalam minyak nilam dilakukan untuk mengadsorpsi zat-zat organik seperti enzim lipase yang menyebabkan tingginya bilangan asam pada minyak nilam. Adsorben adalah suatu bahan yang dapat mengadsorpsi adsorbat atau bahan yang terserap adsorben didalam proses pemurnian terdiri dari dua tipe yakni tipe polar dan tipe non polar. Adsorben polar biasanya digunakan jikan suatu zat yang akan dihilangkan lebih polar dibanding dengan larutannya, sedangkan adsorben non polar biasanya digunakan jika zat yang akan dihilangkan kurang polar.

Adsorben yang digunakan pada penelitian ini adalah zeolit, bentonit, karbon aktif, dan abu gosok yang termasuk dalam golongan adsorben alam. Fungsi dari adsorben alam ini adalah untuk mengadsorpsi zat-zat yang dapat menyebabkan bilangan asam pada minyak nilam. Adsorpsi adalah penyerapan suatu zat pada permukaan suatu zat lain ataupun kecenderungan molekul atau ion dalam larutan untuk berkumpul pada permukaan suatu zat padat. Adsorspsi terjadi oleh adanya gaya atraktif antara molekul yang 
teradsorpsi (adsorbat) dengan material pengadsorpsi (adsorben). Adsorpsi merupakan terjerapnya suatu zat (molekul atau ion) pada permukaan adsorben. Mekanisme proses adsorpsi dapat digambarkan sebagai proses dimana molekul meninggalkan larutan dan menempel pada permukaan zat adsorben secara kimia dan fisika. Suatu molekul dapat teradsorpsi apabila gaya adhesi antara molekul adsorbat dengan molekul adsorben lebih besar dibandingkan dengan gaya kohesi dalam masing-masing molekul proses adsorpsi dilakukan untuk mengurangi senyawa bahan organik yang terdapat dalam limbah cair. Proses adsorpsi ini terjadi karena adanya tegangan permukaan dari abu gosok, makin besar area yang disediakan maka makin banyak molekul yang diserap (Basset, 1994).

Proses adsorpsi dilakukan dengan metode perandaman atau pendiaman tanpa adanya pemanasan dan pengadukan. Padatan adsoben ditimbang sebanyak 0,1 gram lalu dimasukkan kedalam tabung reaksi lalu kedalam tabung reaksi tersebut ditambahkan sebanyak $5 \mathrm{~mL}$ minyak nilam kemudian masing-masing tabung reaksi diadsorpsi selama 6 jam.

Sampel minyak yang telah diadsorpsi selama 6 jam kemudian dipisahkan dari adsorbennya kemudian untuk setiap minyak ditimbang sebanyak 4 gram $\pm 0,05$ gram kemudian minyak nilam ini ditambah dengan $5 \mathrm{~mL}$ etanol netral lalu ditambah dengan 5 tetes indikator phenolphthalein kemudian dititrasi dengan larutan $\mathrm{KOH}$ yang telah distandarisasi sampai terbentuk warna merah muda. Dalam penentuan bilangan asam ini digunakan larutan etanol netral yang berfungsi sebagai pelarut, karena minyak sukar larut dalam air sehingga digunakan pelarut semipolar seperti etanol. Penentuan bilangan asam minyak nilam dilakukan sebelum (tanpa adsorben) dan setelah proses adsorpsi. Bilangan asam minyak nilam untuk tiap-tiap jenis adsorben ditunjukkan pada Tabel 1.

Tabel 1. Hasil penentuan bilangan asam minyak nilam tanpa adsorben dan dengan berbagai jenis adsorben alam

\begin{tabular}{ccc}
\hline Adsorben & $\begin{array}{c}\text { Bilangan } \\
\text { asam } \\
\text { (mg KOH/g } \\
\text { minyak) }\end{array}$ & $\begin{array}{c}\text { Penurunan } \\
\text { Bilangan } \\
\text { Asam (\%) }\end{array}$ \\
\hline $\begin{array}{c}\text { Tanpa } \\
\text { adsorben } \\
\text { Zeolit }\end{array}$ & 3,99 & - \\
Bentonit & 3,80 & 4,71 \\
Abu gosok & 3,93 & 1,45 \\
$\begin{array}{c}\text { Karbon } \\
\text { aktif }\end{array}$ & 3,68 & 7,84 \\
\hline
\end{tabular}

Bilangan asam tanpa menggunakan adsorben diperoleh sebesar 3,99 $\mathrm{mg}$ $\mathrm{KOH} / \mathrm{g}$ minyak digunakan sebagai bilangan asam awal sehingga dapat ditentukan besar penurunan bilangan asam minyak nilam setelah dilakukan proses adsorpsi dengan berbagai jenis adsorben alam. Bilangan asam minyak nilam setelah proses adsorpsi dengan zeolit sebesar 3,80 $\mathrm{mg} \mathrm{KOH} / \mathrm{g}$ minyak atau terjadi penurunan bilangan asam sebesar $4,71 \%$, bilangan asam dengan menggunakan adsorben bentonit sebesar 3,93 $\mathrm{mgKOH} / \mathrm{g}$ minyak atau terjadi penurunan sebesar $1,45 \%$, bilangan asam dengan menggunakan adsorben abu gosok diperoleh sebesar 3,68 $\mathrm{mg} \mathrm{KOH} / \mathrm{g}$ minyak mengalami penurunan sebesar 7,84\%, dan bilangan asam dengan menggunakan adsorben karbon aktif diperoleh sebesar 3,81 mg KOH/g minyak, mengalami penurunan bilangan asam sebesar 4,64\%. Berdasarkan data pada Tabel 1 adsorben yang menyebabkan penurunan bilangan asam paling besar adalah abu gosok yaitu sebesar 7,84\%. Perdana dkk (2012) telah melakukan penelitian mengenai pengaruh abu gosok 
terhadap kadar tanin buah dan tepung mangrove. Adanya penambahan abu gosok dalam proses perebusan menyebabkan penurunan kadar tanin yang signifikan. Hal ini terjadi karena zat-zat racun termasuk tanin ikut terikat pada abu gosok sehingga pembentukan oksida tanin dan proses metabolismenya terhambat (Perdana dkk, 2012). Abu gosok merupakan slah satu pemanfaatan dari sekam padi yang diabukan. Kemampuan adsorpsi abu sekam padi dipengaruhi oleh komposisi abu dan karbon, kemampuan penyerapan total merupakan kombinasi dari penyerapan oleh kation pada abu dan penyerapan oleh karbon hasil pembakaran. (Manullang dan Sacra, 1995). Komposisi terbesar abu sekam padi adalah silika ( $\mathrm{SiO} 2)$ yaitu sebesar 94,4\% dan yang lainnya berupa oksida logam dari $\mathrm{Al}, \mathrm{Ca}, \mathrm{Mg}, \mathrm{Na}, \mathrm{K}$ dan Fe (Folleto dkk, 2006). Abu sekam padi memiliki kemampuan pemucatan yang lebih baik dibandingkan dengan arang aktif. Hal ini disebabkan karena pemucatan pada abu sekam padi merupakan hasil dari perbedaan afinitas yang besar antara kation-kation pada struktur silika abu sekam padi dan karotenoid, sedangkan pada arang aktif, proses pemucatan hanya terjadi karena interaksi hidrofobik antara karotenoid dan arang aktif (Manullang dan Sacra, 1995).

\section{Pengaruh Waktu Kontak}

Waktu kontak merupakan hal yang menentukan dalam proses adsorpsi.Waktu kontak yang lama memungkinkan proses difusi dan penempelan molekul zat terlarut yang teradsorpsi berlangsung lebih baik (Reynold, 1982).

Padatan adsorben abu gosok menghasilkan bilangan asam yang terkecil dibandingkan dengan adsorben lainnya yaitu sebesar 3,68 $\mathrm{mg} \mathrm{KOH} / \mathrm{g}$ minyak dengan prosentase penurunan sebesar 7,84 $\%$, sehingga adsorben abu gosok ini digunakan untuk mengadsorpsi minyak nilam dengan beberapa variasi waktu. Abu gosok diketahui dapat menyerap cairan sel, mengikat racun dan mengikat zat antinutrisi (Pembayun, 2000).Hal inilah yang menjadi awal pemikiran serta adanyakemungkinan bahwa abu gosok diharapkan mampu untuk mengurangi bilangan asam dengan jumlah yang cukup besar pada minyak nilam. Tabel 2 menunjukkan hasil dari adsorpsi minyak nilam dengan adsorben abu gosok dengan beberapa variasi waktu.

Tabel 2. Pengujian bilangan asam dengan beberapa variasi waktu

\begin{tabular}{ccc}
\hline $\begin{array}{c}\text { Waktu } \\
\text { Kontak } \\
\text { (Jam) }\end{array}$ & $\begin{array}{c}\text { Bilangan } \\
\text { asam } \\
(\mathbf{m g} \\
\text { KOH/g } \\
\text { minyak) }\end{array}$ & $\begin{array}{c}\text { Penurunan } \\
\text { Bilangan } \\
\text { Asam (\%) }\end{array}$ \\
\hline $\mathbf{3}$ & 3,74 & 6,24 \\
$\mathbf{6}$ & 3,68 & 7,87 \\
$\mathbf{9}$ & 3,55 & 11,13 \\
$\mathbf{1 2}$ & 3,48 & 12,74 \\
$\mathbf{1 5}$ & 3,42 & 14,34 \\
$\mathbf{2 1}$ & 3,42 & 14,34 \\
\hline
\end{tabular}

Data dari Tabel 2 menujukkan bilangan asam minyak nilam dengan variasi waktu kontak 3, 6, 9, 12, 15, dan 21 jam. Penurunan bilangan asam terjadi pada waktu kontak antara 3-15 jam. Bilangan asam minyak nilam pada waktu kontak 21 jam memiliki nilai yang sama besar dengan waktu kontak 15 jam yaitu $3,42 \mathrm{mg} \mathrm{KOH} / \mathrm{g}$ minyak atau terjadi penurunan sebesar 14,34\%. Hal ini menunjukkan bahwa adsorben abu gosok telah jenuh dan waktu yang optimum untuk proses adsorpsi adalah $15 \mathrm{jam}$. Seiring berjalannya waktu, perlahan proses adsorpsi menjadi tidak efektif lagi dan pada akhirnya,abu gosok yang telah jenuh tidak bisa menyaring atau menyerap zatzat organik dalam minyak nilam kembali. Berdasarkan data tersebut dapat dikatakan bahwa kapasitas adsorpsi abu gosok pada 
penurunan bilangan asam per 0,1 gram adsorben adalah sebesar $14,34 \%$.

Gambar 1 menunjukkan hubungan antara waktu kontak terhadap penurunan bilangan asam. Semakin lama waktu kontak akan menyebabkan penurunan bilangan asam semakin besar. Penurunan bilangan asam minyak nilam meningkat sekitar $0,7 \%$ per jamnya untuk berat adsorben 0,1 gram.

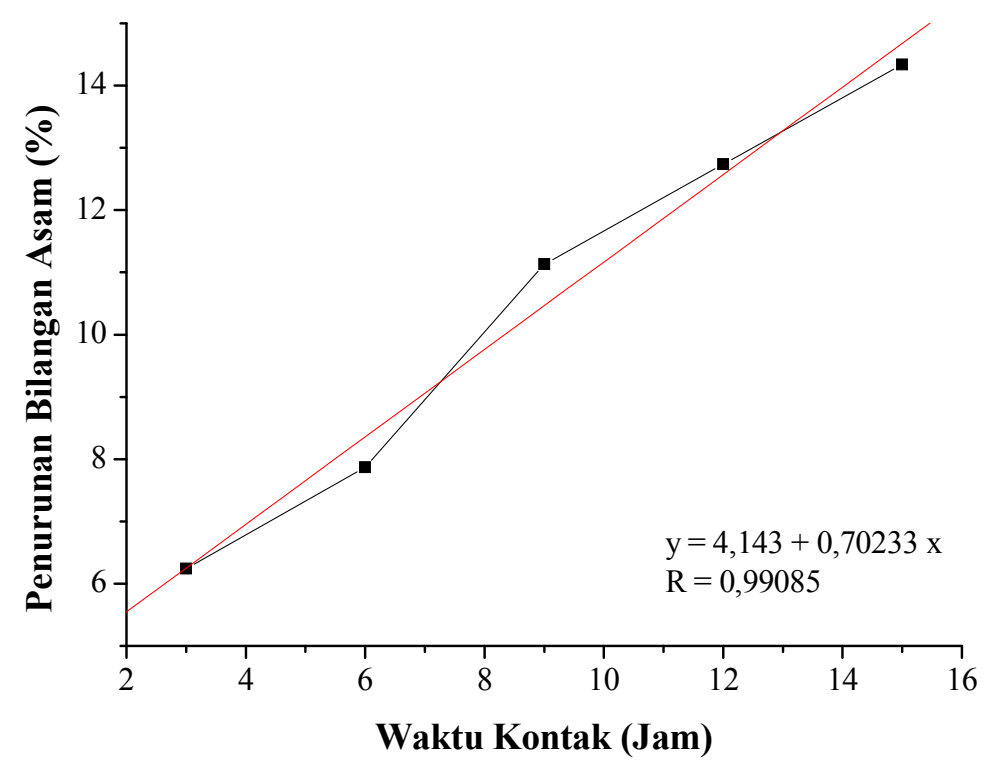

Gambar 1. Hubungan antara waktu kontak dan penurunan bilangan asam minyak nilam dengan abu gosok sebagai adsorben

\section{Kesimpulan}

Pemanfaatan adsorben alam dapat menyebabkan penurunan bilangan asam minyak nilam. Penggunaan abu gosok sebagai adsorben menyebabkan penurunan bilangan asam paling baik yaitu sebesar $3,68 \mathrm{mg} \mathrm{KOH} / \mathrm{g}$ minyak atau mengalami penurunan sebesar $7,84 \%$. Semakin lama waktu kontak antara adsorben dan minyak dapat menyebabkan semakin besranya penurunan bilangan asam. Waktu kontak maksimum untuk abu gosok adalah 15 jam dengan kapasitas maksimum adsorpsi sebesar $14,34 \%$ per 0,1 gram adsorben.

\section{Daftar Pustaka}

Bassett, J., 1994,Buku Ajar Vogel Kimia Analisis Kuantitatif Anorganik. Penerbit buku Kedokteran EGC, Jakarta

Folleto, E. L., Ederson, G., Leonardo, H. O., Sergio, J., 2006, Conversion of Rice Hulk Ash Into Sodium Silicate, Material Research, 9(3), 335-338

Kemendag, 2011,Laporan Akhir Tahun Kementrian Perdagangan, Kementerian Perdagangan Republik Indonesia (Kemendag RI), Jakarta

Manullang, M., dan Sacra F., 1995, Pemanfaatan Abu Sekam Padi

EKSAKTA Vol. 14 No. 1 Februari 2014, 27-33 
Sebagai Pemucat Minyak Kelapa, Minyak Wijen, dan Menyak Kelapa Sawit, Buletin Teknik dan Industri Pangan, 6, 27-36

Sastrohamidjojo, H., 2004,Minyak Atsiri,UGM Press, Yogyakarta

Sariadi, 2012, Pemurnian Minyak Nilam dengan Proses Adsorpsi Menggunakan Bentonit,Jurnal Teknologi, 12(2), 100-104

Alam, P. N., 2007, Aplikasi Proses Pengkelatan untuk Peningkatan Mutu Minyak Nilam Aceh,Jurnal Rekayasa Kimia dan Lingkungan, 6(2), 63-66

Foletto, E.L., Volzone, C. dan Porto, L.M., 2006, Clarification of cotton seed oil: how structural properties of treated bentonites by acid affect bleaching efficiency,Latin American Applied Research,36, 37-40

Topallar, H., 1998, The Adsorption Isotherms of the Bleaching ofSunflower-Seed Oil,Turkish Journal of Chemistry, 22, 143-148.
Purwaningsih, S., Arung E.T., dan Muladi, S., 2000,Pemanfaatan Arang Aktif Cangkang Kelapa Sawit Sebagai Adsorben Pada Limbah Cair Kayu Lapis,Fakultas Kehutanan Universitas Mulawarman, Samarinda

Perdana, Y. S., Nirwani S., Supriyantini, E., 2012, Pengaruh Kadar Abu Gosok Selama Perebusan Dan Lama Perendaman Air Terhadap Kadar Tanin Buah Dan Tepung Mangrove (Avicennia marina),Journal of Marine Research, 1, 226-234

Pembayun, R., 2000, Hydro Cyanic Acid and Organoleptic Test on Gadung Instant Rice from Various Methods of Detcsification,Seminar Nasional Industri Pangan,13, 97-107

Reynold, T. D., 1982,Unit Operations And Processes In Environmental Engineering, Brooks/Cole Engineering Division Monterey, California.

SNI, 2006,Minyak Nilam (06-2385-2006), Badan Standarisasi Nasional, Jakarta. 